\title{
TEKNIK KURATIF TERHADAP COMPUTER VISION SYNDROME (CVS) PADA SISWA MENENGAH KEJURUAN KOMPUTER MELALUI AKUPRESUR MATA
}

\author{
Nada Cindya ${ }^{1}$, Ayu Anita ${ }^{2}$, Yurike Reza ${ }^{3}$, Riri Novayelinda ${ }^{4}$ \\ 1,2,3,4Fakultas Ilmu Keperawatan Universitas Riau Jalan Pattimura No 9 Gedung G Pekanbaru Riau \\ Kode Pos 28131 Indonesia \\ Email: nada24nacin@gmail.com
}

\begin{abstract}
Abstrak
Computer Vision Syndrome (CVS) adalah kumpulan gejala visual sebagai akibat interaksi yang panjang dengan media elektronik seperti komputer, maupun perangkat digital lainnya. Tujuan dari penelitian ini untuk mengidentifikasi efektivitas akupresur mata sebaagai teknik kuratif terhadap Computer Vision Syndrome (CVS). Jenis penelitian ini adalah kuantitatif dengan quasy eksperimen. Sampel dari penelitian adalah siswa sekolah kejuruan komputer yang berada pada usia remaja menengah sebanyak 50 responden. Pemilihan sampel dilakukan menggunakan metode Purposive sampling. Analisis statistik yang digunakan adalah Wilcoxon, paired sample test dan Mann Whitney. Sebelum penelitian pada kelompok eksperimen menunjukkan keluhan nilai CVS tertinggi yaitu 23 poin, kemudian setelah mendapat perlakuan turun drastis pada nilai minimum 0 poin, sejalan hal tersebut hasil analisa menunjukkan bahwa akupresur mata menurunkan kejadian CVS dengan nilai rata-rata pretest 12,28 dan posttest 5,44 ( $p$ value $=0,000)$. Pada akhirnya ditarik kesimpulan bahwa akupresur maa sebagai salah satu alternatif kuratif komplementer pada kejadian Computer Vision Syndrome.
\end{abstract}

Kata Kunci: Computer Vision Syndrome, akupresur mata, siswa

\begin{abstract}
Computer Vision Syndrome (CVS) is symptoms of visual which is resulted from using for a long time interaction with electronic media such as computers; or digital device. The purpose of study to identify the effectiveness of eye acupressure as a curative technique for Computer Vision Syndrome (CVS). The type of this research quantitative with quasy experimental design. The sample of this study was students of Vocational school of Computer Major who were at the age of middle adolencent as many as 50 respondents and identified have Computer Vision Syndrome. The sample were selected by using Purposive sampling method. The analysis statistic used Wilcoxon, paired sample test and t-Independent. Before studies in experimental groups showed highest complaint of CVS with 23 points, then after getting the treatment drastically decrease at minimum 0 point, accordance with analysis statistic showed that acupresure can reduce the CVS significantly with mean prestest 12,28 and posttest 5,44 ( $p$ value $=0,000$ ). It is concluded that eyes acupresure as a one of curative alternative in complementary for Computer Vision Syndrome.
\end{abstract}

Keywords: Computer Vision Syndrome, eyes acupressure, student

\section{PENDAHULUAN}

Kemajuan revolusi industri 4.0 berkembang semakin pesat. Demikian halnya dengan teknologi informasi dan komunikasi yang penggunaanya tidak hanya sebatas keperluan pekerjaan tetapi juga distraksi rasa jemu, seperti penggunaan browsing maupun game

online. Menurut Roselin (2010), perkembangan teknologi informasi seperti internet sudah mampu menciptakan masyarakat dunia global dan menciptakan suatu perubahan kehidupan bagi masyarakat. Tanpa disadari manusia telah 
Nada Cindya ${ }^{1}$, Ayu Anita ${ }^{2}$, Yurike Reza ${ }^{3}$ Riri Novayelinda ${ }^{4}$, Teknik Kuratif terhadap Computer Vision Syndrome (CVS) pada Siswa Menengah Kejuruan Komputer melalui Akupresur Mata

berada dalam dua keadaan komunitas masyarakat yang harus diikuti, yaitu komunitas masyarakat nyata dan komunitas masyarakat maya (cyber community).

Asosiasi Penyelenggara Jasa Internet Indonesia (APJII) tahun 2014, mengungkapkan jumlah pengguna internet di Indonesia tahun mencapai 88 juta orang hingga akhir tahun 2014. Berdasarkan populasi, jumlah pengguna Internet terbesar adalah di provinsi Jawa Barat sebanyak 16.4 juta, diikuti oleh Jawa Timur 12.1 juta pengguna dan Jawa Tengah 10.7 juta pengguna. Pulau Sumatera menyumbang 18,6 juta pengguna dimana daerah Riau sendiri telah mencapai angka 1.8 juta pengguna dengan angka penetrasi sebesar 29\%. Adapun media eletronik yang digunakan dipulau Sumatera berupa telepon seluler sebanyak $71 \%$ disusul penggunakan notebook/laptop sebanyak 32\%. Menurut Kompas Tekno, (2014) mengungkapkan, bahwa 69 persen responden menggunakan komputer untuk mengakses internet, sekitar sepertiga (34\%) menggunakan laptop, dan $2 \%$ terhubung melalui video game.

Berdasarkan hasil Sensus Penduduk BPS tahun (2010), tercatat bahwa penduduk Indonesia berjumlah 237,6 juta jiwa dan 64 juta jiwa diantaranya berusia remaja. Menurut Badan Kependudukan dan
Keluarga Berencana (BKKBN) 2014, rentang usia remaja adalah 10-24 tahun dan belum menikah. Memasuki usia remaja seseorang cenderung untuk mencoba hal yang baru sebagai aktualisasi dari pencarian jati dirinya termasuk penggunaan media eletronik. Intensitas penggunaan media eletronik diperkirakan meningkat seiring berjalannya waktu (Azkadina, 2012). Hal ini mengakibatkan dampak yang signifikan terhadap masalah kesehatan visual yang jika tidak tertangani akan menurunkan produktivitas (Shantakumari, Eldeeb, Sreedharan, 2014).

Menurut Anggrainy, Ashar dan Lubis (2018), Kumpulan gejala yang mengakibatkan gangguan pada mata dikarenakan fokus penglihatan dalam waktu yang panjang didepan komputer, maupun perangkat digital lainnya disebut dengan Computer vision Syndrome (CVS). Gejala tersebut meliputi gejala okular internal, okular eksternal, gejala visual, dan gejala yang berhubungan dengan muskuloskeletal (Gawrinsankaran \& Sheedy, 2014).

Hasil penelitian yang dilakukan oleh Permana, Koesyanto dan Mardiana (2015), menunjukan bahwa Computer vision Syndrome disebabkan beberapa faktor antara lain durasi penggunaan, jarak mata dengan monitor, intensitas penerangan, serta sikap tubuh yang tidak ergonomis 
Jurnal Ners Indonesia, Vol.10 No.1, September 2019

saat menggunakan media elektronik. Menurut Wong (2012), akupresur sebagai salah satu jenis terapi komplementer berperan dalam menjaga keseimbangan tubuh salah satunya dalam mengoptimalkan kesehatan visual.

Berdasarkan uraian tersebut, peneliti ingin melakukan penelitian guna mengetahui apakah teknik akupresur mata dapat menjadi tindakan kuratif terhadap CVS. Melalui sasaran remaja pertengahan yang duduk dibangku sekolah kejuruan komputer yang aktif menggunakan media elektronik sebagai penunjang belajar dikesehariannya, peneliti tertarik untuk melakukan penelitian guna mengetahui apakah teknik akupresur mata dapat menjadi tindakan kuratif terhadap CVS. Sehingga diharapkan CVS yang dialami siswa dapat teratasi dan proses pembelajaran berlangsung lebih baik.

\section{METODE PENELITIAN}

Penelitian ini merupakan jenis penelitian kuantitatif dengan desain quasy experiment melalui rancangan pretest dan posttest. Adapun teknik pengambilan sampel (sampling) dalam penelitian ini menggunakan teknik non-probability yaitu purposive sampling yaitu penetapan sampel berdasarkan pertimbangan terkait ciri dan sifat mewakili karakteristik populasi. Penelitian ini melibatkan sebanyak 50 responden yang terbagi dalam 2 jenis kelompok yaitu kelompok kontrol dan kelompok eksperimen.
Analisis data melibatkan data univariat dan bivariat yang sebelumnya telah dilakukan pengujian homogenitas menggunakan Levene's test dan normalitas data menggunakan Shapiro-Wilk. Dalam hal ini untuk melihat kondisi Computer Vision Syndrome (CVS) pada kelompok kontrol dilakukan uji dependent sample t-test, sedangkan pada kelompok eksperimen dilaksanakan analisis uji statistik Wilcoxon untuk melihat pengaruh intervensi akupresur mata terhadap Computer Vision Syndrome (CVS). Selanjutnya untuk membandingkan pengaruh intervensi pada kedua kelompok dilakukan analisis hipotesis uji beda dua mean independent sample t-test guna melihat adanya perbedaan atau tidak adanya perbedaan posttest gejala Computer Vision Syndrome (CVS).

Tahap pre-test diawali dengan penyebaran kuesioner Computer Vision Syndrome kepada responden untuk kemudian dilakukan skrining terhadap hasil yang didapatkan sesuai dengan kriteria yang diharapkan peneliti dimana responden merupakan individu yang positif dinyatakan mengalami CVS.

Melalui penilaian dari skrining yang didapatkan, maka sampel dibagi dalam dua jenis kelompok yaitu kelompok kontrol dan kelompok eksperimen. Selanjutnya tahapan akupresur dimulai sesuai instruksi dan panduan dari leaflet yang diberikan. Intervensi 
Nada Cindya ${ }^{1}$, Ayu Anita ${ }^{2}$, Yurike Reza ${ }^{3}$ Riri Novayelinda ${ }^{4}$, Teknik Kuratif terhadap Computer Vision Syndrome (CVS) pada Siswa Menengah Kejuruan Komputer melalui Akupresur Mata

dilaksanakan 1 kali sehari sekitar 15-20 menit selama 4 hari berturut-turut kepada kelompok eksperimen. Tahapan intervensi dimulai dengan sterilisasi tangan.

Penekanan dilakukan pada titik akupresur masing-masing sebanyak 20 kali tekanan secara sirkular berlawanan arah jarum jam, dengan kekuatan tekanan dianggap cukup apabila sepertiga kuku menjadi putih pada saat penekanan dilakukan. Akupresur dimulai dengan tahapan rileksasi nafas dalam dan penekanan pada acupoint GB-20 serta GB-21. Selanjutnya fokus pada regio wajah akupresur meliputi acupoint EX-HN 3/Yingtang, acupoint BL-2, medial acupoint EX-HN 4, acupoint EX-HN 5, acupoint SJ- 23, acupoint ST-2, dan diakhiri pada acupoint BL-1.

Selang satu hari setelah 4 hari berturutturut dilakukan intervensi, maka pada hari keenam peneliti mengidentifikasi kembali kondisi Computer Vision Syndrome (CVS) yang dialami responden menggunakan kuesioner. Hasil skoring dari kuesioner kemudian dicatat pada lembar penilaian. Setelah proses pengumpulan data selesai, peneliti melakukan analisis menggunakan uji statistik sesuai metode yang ada.

\section{HASIL PENELITIAN}

Tabel 1.

Data demografi berdasarkan usia, jenis kelamin, durasi penggunaan

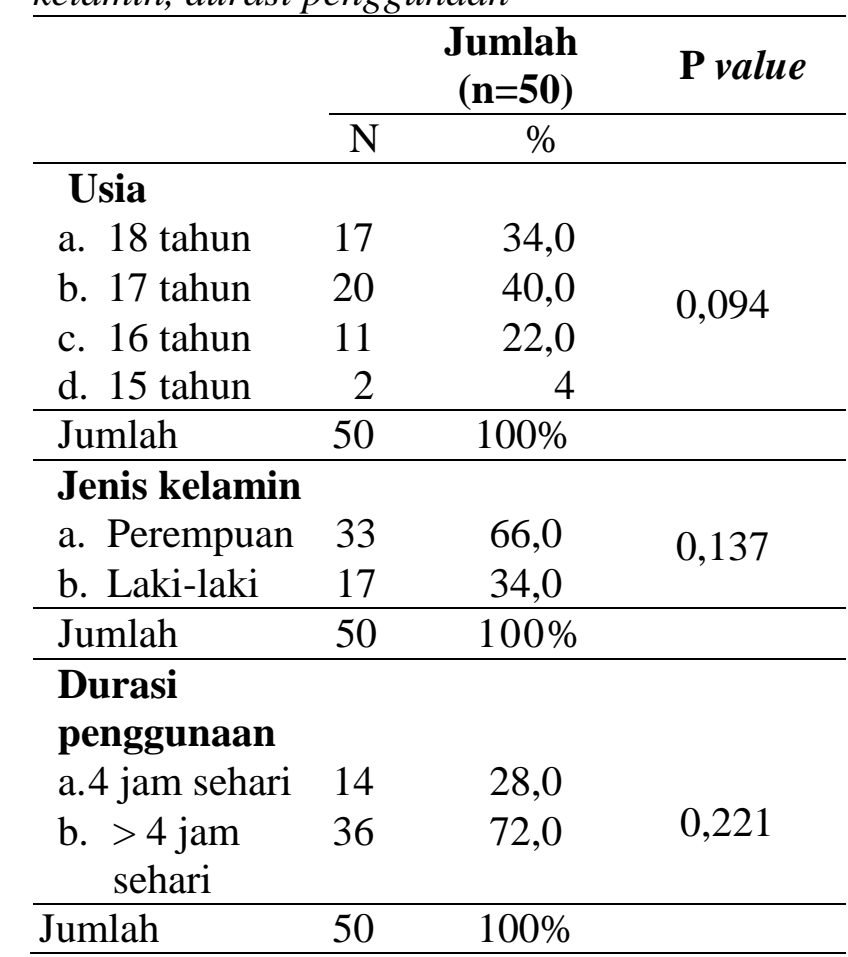

Berdasarkan tabel 1 didapatkan data bahwa dari 50 responden yang diteliti mayoritas responden berada pada usia 17, yakni sebanyak 20 orang $(40,0 \%)$, sebagian besar berjenis kelamin perempuan sejumlah 33 orang $(66,4 \%)$, dengan durasi penggunaan media elektronik terbesar yaitu lebih dari 4 jam dalam sehari sebanyak 36 orang $(72,0 \%)$. Setelah dilakukan uji homogenitas untuk data demografi, sehingga didapatkan data yang homogen dimana usia $p$ value 0,094>a $(0,05)$, jenis kelamin $p$ value $0,134>a(0,05)$, adapun durasi penggunaan media elektronik didapatkan $p$ value $0,221>$ a $(0,05)$, darihasil tersebut menunjukkan bahwa kedua data sama atau homogen. 
Tabel 2.

Uji homogenitas CVS sebelum intervensi pada kelompok eksperimen dan kelompok kontrol

\begin{tabular}{lccl}
\hline Variabel & Mean & SD & P value \\
\cline { 1 - 2 } $\begin{array}{l}\text { Kelompok } \\
\text { Eksperimen }\end{array}$ & 12,28 & 5,519 & 0,835 \\
\cline { 1 - 2 } $\begin{array}{l}\text { Kelompok } \\
\text { Kontrol }\end{array}$ & 13,22 & 5,278 & \\
\hline
\end{tabular}

Berdasarkan tabel diatas, didapatkan data yang homogen dimana mean pretest pada kelompok eksperimen dan kelompok kontrol masing-masing dan 12,28 dan 13,12 dengan $p$ value kedua kelompok ialah $0,835>$ a $(0,05)$. Hal ini menunjukkan bahwa sebelum mendapatkan intervensi kedua kelompok memiliki variasi yang sama.

Tabel 3.

Uji normalitas data

\begin{tabular}{llcc}
\hline \multirow{2}{*}{ Value } & Kelompok & N & $P$ \\
\hline Kelompok & & & \\
\cline { 2 - 4 } Kontrolest & 25 & 0,422 \\
\hline Kelompok & Posttest & 25 & 0,102 \\
\cline { 2 - 4 } Eksperimest & 25 & 0,018 \\
\cline { 2 - 4 } & Posttest & 25 & 0,098 \\
\hline
\end{tabular}

Berdasarkan uji Shapiro-Wilk yang telah dilakukan didapatkan nilai pretest kelompok kontrol $p$ value $0,422>$ a $(0,05)$ dan posttest $0,102>$ a $(0,05)$ adapun posttest kelompok eksperimen $p$ value $0,098>a(0,05)$ sedangkan pada pretest eksperimen data tidak terdistribusi normal dimana $p$ value $0,018<\mathrm{a}$ $(0,05)$ dengan demikian tidak memenuhi syarat untuk dilakukan uji $t$ test sehingga menggunakan uji alternatif.
Uji statistik alternatif yang digunakan untuk melihat perbedaan pretest dan posttest pada kelompok eksperimen menggunakan uji Wilcoxon, sedangkan pretest dan posttest untuk kelompok kontrol menggunakan uji $t$ dependent/ berpasangan, adapun untuk perbandingan kedua kelompok digunakan uji $t$ independent.

Tabel 4.

Skor Computer Vision Syndrome (CVS) pretest dan posttest Intervensi pada Kelompok eksperimen dan kelompok kontrol

\begin{tabular}{llrll}
\hline Variabel & & Median & SD & \multicolumn{1}{c}{$\begin{array}{c}\boldsymbol{P} \\
\text { value }\end{array}$} \\
\hline Ekeperimen & Pretest & 12,28 & 5,519 & 0,000 \\
\cline { 2 - 4 } & Posttest & 5,44 & 3,980 & \\
\hline \multirow{2}{*}{ Kontrol } & Pretest & 13,12 & 5,278 & 0,001 \\
\cline { 2 - 4 } & Posttest & 15,76 & 5,380 & \\
\hline
\end{tabular}

Berdasarkan tabel diatas terlihat bahwa kelompok eksperimen memiliki perbedaan Computer Vision Syndrome (CVS) dimana pada pretest didapatkan mean senilai 12,28 dengan standar deviasi 5,519 sedangkan posttest memiliki mean 5,44 dengan standar deviasi 3,980. Hasil analisis berdampak signifikan dimana $\mathrm{p}$ value $0,000<\mathrm{a}(0,05)$. Sehingga dapat disimpulkan bahwa gejala Computer Vision Syndrome (CVS) menurun setelah diberikan perlakuan akupresur mata yaitu sebanyak 6,84 .

\section{PEMBAHASAN}

Pada kelompok kontrol mean Computer Vision Syndrome (CVS) pada pretest yaitu 13,12 dengan standar deviasi 5,278 sedangkan 
Nada Cindya ${ }^{1}$, Ayu Anita ${ }^{2}$, Yurike Reza ${ }^{3}$ Riri Novayelinda ${ }^{4}$, Teknik Kuratif terhadap Computer Vision Syndrome (CVS) pada Siswa Menengah Kejuruan Komputer melalui Akupresur Mata

mean pada posttest senilai 15,76 dengan standar deviasi 5,380. Sehingga dari hasil analisis dapat diidentifikasi bahwa pada kelompok kontrol terdapat perbedaan dimana peningkatan Computer Vision Syndrome (CVS) yaitu 2,64 dengan $p$ value yaitu 0,001 > $a(0,05)$.

\section{Computer Vision Syndrome timbul} sebagai salah satu akibat dari ergonomika benda. Penggunaan media elektronik yang tidak tepat dapat berakibat pada kesehatan (Sulianta, 2013). Hasil analisis uji statisk menunjukkan rentang nilai tertinggi yang semula 23 poin didapatkan pada dua kelompok turun drastis pada nilai minimum kelompok eksperimen yaitu 0 poin, sedangkan kelompok kontrol 6 poin. Hal ini mengidentifikasikan bahwa kelompok eksperimen yang telah mendapatkan perlakuan akupresur mata CVS yang dialaminya sembuh secara signifikan. Adapun pada kelompok kontrol walaupun terjadi penurunan, namun nilai belum bermakna dimana skor minimum yang didapatkan adalah 6 poin, hal ini menunjukkan bahwa responden masih tergolong mengalami Computer Vision Syndrome (CVS).

Kompleksitas acupoint yang diterapkan dalam intervensi penelitian ini memberikan efek kuratif yang baik dibandingkan hanya menggunakan satu atau beberapa acupoint saja. Hal ini sejalan dengan penelitian yang dilakukan oleh Kwon dan Lee (2018), yang membandingkan perlakuan berbagai jenis terapi akupresur dengan tingkat kesembuhan, dari hasil yang didapatkan menunjukkan bahwa tingkat clinical effective rate mencapai $100 \%$ pada intervensi yang melibatkan banyak acupoint.

Intervensi yang dilakukan pada penelitian ini selama 4 hari berturut-turut dalam 1 sesi berpengaruh terhadap manfaat yang didapatkan. Senada dengan penelitian oleh Ho dalam Kwon dan Lee (2018), yang menunjukkan terdapat hubungan antara periode dan sesi intervensi terhadap tingkat keberhasilan, yang mana diketahui pelakuan dengan periode selama 3-5 hari dan sesi tidak lebih dari 2 kali dalam sehari berimplikasi pada tingkat kesembuhan senilai $100 \%$.

Akupresur mata melibatkan 9 acupoint yang tersebar dibeberapa regio tubuh. Menurut Zhao, Dennis, dan Lam (2010), acupoint BL-2 dan EX-HN 5 dapat memodulasi aktivasi korteks visual, lebih dari itu acupoint ini terbukti efektif dalam meningkatkan aliran darah kepembuluh darah otak dan okular (termasuk koroid), menstimulasi pertumbuhan saraf retina dan menyebabkan perubahan metabolisme pada sistem saraf pusat.

Berdasarkan penelitian Fabrin (2015) mengenai fungsional acupoint EX-HN 4 memaparkan bahwa akupresur menghasilkan efek langsung pada sistem motorik dan mempertahankan keseimbangan energi serta harmonisasi dalam tubuh. Akupresur juga memaikan peran penting sebagai analgesik 
alami. Menurut Chiu et.al (2003), bahwa ambang batas nyeri menurun, meliputi hipotalamus, nukleus acumbens dan mesencephalon yang merupakan jalur mediasi sentral. Hal ini sejalan dengan dengan penelitian yang dilakukan oleh Pei (2016), yang menunjukkan bahwa intervensi pada GB20 dapat memperbaiki gejala sakit kepala sebelah dengan mengubah sistem modulasi nyeri yang menurun.

Hasil lain menunjukkan bahwa akupresur dapat menurunkan kecemasan. Penelitian yang dilakukan oleh Chi (2016), menyatakan bahwa metode akupresur pada acupoint GB-21 dapat menvasodilatasi dan menstimulasi sirkulasi darah untuk meningkatkan metabolisme dan membantu mengeliminasi racun dari tubuh. Sementara penekanan acupoint GB-20 memodulasi fungsi meridian serta menurunkan nyeri pada kepala. GB 20 berhubungan dengan CGRP yaitu hormon yang memiliki peranan penting dalam respon inflamasi dengan cara memperlebar arteri meningeal (Zhou, 2017 ).

Sagara (2006) menyatakan bahwa acupoint pada beberapa meridian seperti GB20 dan BL-2 terbukti meningkatkan kualitas penglihatan melalui beberapa mekanisme, salah satunya dengan penekanan aktivitas saraf simpatis dan peningkatan aliran darah mata. Pada sistem syaraf stimulasi yang diberikan menginduksi eksitasi serabut eferen, dengan melibatkan respon refleks berupa pelebaran pupil melalui saraf eferen parasimpatis kranial ke-tiga. Selain itu stimulus yang diberikan pada acupoint tersebut, berkontribusi pada peningkatan aliran darah koroid mata yang kemudian dapat diukur melalui flowmeter. Dengan adanya peningkatan darah koroid dan keseimbangan sistem syaraf otonom fungsi optik berjalan dengan baik.

Akupresur yang diberikan pada regio acupoint SJ-23 and Yingtang berperan memberikan efek relaksasi serta menurunkan kecemasan (Valiee, 2012). Selain itu menurut Gong dan Sun (2007), acupoint SJ 23 berfungsi mengatur kelembaban mata dimana stimulasi yang diberikan pada titik ini meningkatkan sintesis dan sekresi lakrimal dengan merangsang fungsi kantung lakrimalis sebagai tempat untuk memproduksi kelenjer air mata.

Adapun acupoint ST-2 menurut Yeh, Chen, Chen dan Lin (2008), berperan penting dalam memperbaiki kesehatan visual akibat gejala akut pada fungsi penglihatan serta gangguan refraksi, demikian halnya dengan BL-1 menurunkan kelelahan otot mata (Lin, Vasudevan \& Liang, 2013).

\section{SIMPULAN}

Berdasarkan hasil dari penelitian yang melibatkan 50 responden yang terdiri dari siswa sekolah menengah atas kejuruan dapat disimpulkan bahwa pada remaja usia terbanyak 17 tahun, mayoritas perempuan 
Nada Cindya ${ }^{1}$, Ayu Anita ${ }^{2}$, Yurike Reza ${ }^{3}$ Riri Novayelinda ${ }^{4}$, Teknik Kuratif terhadap Computer Vision Syndrome (CVS) pada Siswa Menengah Kejuruan Komputer melalui Akupresur Mata

sejumlah 33 orang, dengan rata-rata durasi penggunaan media elektronik lebih dari 4 jam dalam sehari sebanyak 36 orang.

Hasil statitistik penelitian ini menunjukkan bahwa nilai rata-rata kelompok eksperimen mengalami penurunan yang drastis dari keluahan yang semulanya cukup berat menjadi membaik bahkan hingga sembuh total. Sedangkan pada kelompok kontrol terjadi perubahan mean pretest keposttest yang meningkat. Dari perbandingan kedua kelompok didapatkan $p$ value yang signifikan. Sehingga dapat dapat dirumuskan bahwa akupresur mata dapat menjadi Teknik Kuratif Terhadap Computer Vision Syndrome (CVS) Pada Siswa Menengah Kejuruan Komputer.

\section{SARAN}

Akupresur mata menjadi pilihan alternatif bagi penatalaksanaan Computer Vision Syndrome (CVS). Peneliti selanjutnya diharapkan dapat melanjutkan penelitian ini untuk menilai efektivitas akupresur mata terhadap kelainan refraksi mata.

\section{DAFTAR PUSTAKA}

Azkadina, A. (2012). Hubungan antara Faktor Resiko Individual dan Komputer terhadap Kejadian Computer Vision

Syndrome (CVS). Skripsi. Universitas Diponegoro, Semarang.

Chi, L.M., Lin, L.M., Chen, C.L., Wang, S.F., Lai, H.L., \& Peng, T.C. (2016).The Effectiveness of Cupping Therapy on Relieving Chronic Neck and Shoulder Pain: A Randomized Controlled Trial.
Hindawi Publishing Corporation Evidence-Based Complementary and Alternative Medicine; 7

Chiu, J.H., Chung, M.S., Cheng, H.C., Yeh, T.C Hsieh, J.C., Chang, C.Y., Kuo, W.Y., Cheng, H., \& Ho, L.T.(2003). Different Central Manifestations in Response to Electroacupuncture at Analgesic and nonanalgesic acupoints in rats: a manganese enhanced functional magnetic resonance imaging study. The Canadian Journal of Veterinary Research; 67:94.101

Fabrin, S., Soares, N., Yoshimura, D.P., Regalo, S.C.H., Verri, E.D., Vianna, J.R.D.F. Regueiro, E.M.G., \& Silva, J.R.T.D. (2016). Effects of Acupuncture at the Yintang and the Chengjiang Acupoints on Cardiac Arrhythmias and Neurocardiogenic Syncope in Emergency First Aid. Journal of Acupuncture and Meridian Studies, 9(1):26-30

Gong, L., \& Sunn, X. (2007). Treatment of Inractable Sry Eyes: Tear Secretion Increase and Morphological Change of Lacrimal Gland of Rabbit after Acupuncture. Acupuncture \& ElectroTherapeutics Research, 32(3-4), 223233

Hui, K.K.S., Liu, J., Makris, N., Gollub, R.L., Chen, A.J.W., Moore, C.I., Kennedy, DN., Rosen, B.R., \& Kwong, K.K. (2000). Acupuncture modulates the limbic system and subcortical gray structures of the human brain: evidence from fMRI studies in normal subjects. Hum Brain Mapp, 9:13-25

Indonesia, A. P. J. I. (2014). Infografis Peneterasi dan Perilaku Pengguna Internet Indonesia. ID: APJII.

Lin, Z., Vasudevan, B., Jhanji, V., Gao, T. Y., Wang, N. L., Wang, Q \& Liang, Y. B. (2013). Eye Exercise of Acupoints: Their Impact on Refractive Error and Visual Symptoms in Chinese Urban Children. BMC Complementary and Alternative Medicine,13(1); 306 
Pei, P., Liu, L., Zhao, L., Cui, Y., Qu, Z., \& Linpeng Wang, L. (2016). Effect of Electroacupuncture Pretreatment at GB20 on Behaviour and the Descending Pain Modulatory System in a Rat Model

Of Migraine. Acupunct Med; 34:127135

Roselin. (2010).Transformasi Masyarakat Nyata Menuju Masyarakat Maya Melalui Internet. Skripsi. Medan, Universitas Sumatera Utara.

Sagara, Y., Fuse, N., Seimiya, M., Yokokura, S., Watanabe, K., Nakazawa, T., Kurusu, M., Seki, T., \& Tamai, M. (2006). Visual Function with Acupucture tested by Visual Evoked Potential. Tohoko J. Exp Med., 209, 235-241

Sulianta, F. (2013). IT Ergonomics. Elex Media Komputindo

Valiee, S., Bassampour, S.S., Nasrabadi, N.A., Pouresmaeil, Z., \& Abbas Mehran, A. (2012). Effect of Acupressure on Preoperative Anxiety: A Clinical Trial. Journal of Perianesthesia Nursing, Vol 27, No 4;259-266

Wang, S.Q., Liang, W.X., Huang, G.H., \& Wu, P.C (2011). Randomized Controlled Clinical Trials Foracupuncture Treatment of Spastic Cerebral Palsy Children by Bilateral Horizontal Puncturing from Yuzhen to Tianzhu. Acupuncture research, 36(3); 215-219.

Yang, J., Zeng, F., Feng, Y., Fang, L., Qin, W., Liu, X., Song, W., Xie, H., Chen, \& J., Liang, F. (2012). A PET-CT study on the specificity of acupoints through acupuncture treatment in migraine patients. BMC Complementary and Alternative Medicine, 12:123

Zhao, L.P., Liu, L., Pei, P., Qu, Z.Y., Zhu, Y., Wang, L. (2017). Electroacupuncture At Fengchi (GB20) Inhibits Calcitonin Gene-Related Peptide Expression in the Trigeminovascular System of a Rat Model of Migraine. Neural Regeneration Research; 12(5):804811. 